\title{
Impact of Contaminants in Motor Oil on the Wear of Aluminum Parts of the Internal Com- bustion Engine
}

Zdeněk Aleš ${ }^{1}$, Jindřich Pavlů ${ }^{1}$, Jaroslava Svobodová ${ }^{2}$, Marián Kučera ${ }^{3}$, Monika Hromasová ${ }^{4}$, Martin Pexa ${ }^{1}$

${ }^{1}$ Faculty of Engineering, Czech University of Life Sciences Prague, Department for Quality and Dependability of Machines, Kamýcká 129, 16521 Prague 6 - Suchdol, Czech Republic, E-mail: ales@tf.czu.cz, pavluj@tf.czu.cz pexa@tf.czu.cz

${ }^{2}$ Faculty of Mecahnical Engineering, Jan Evangelista Purkyně University in Ústí nad Labem, Pasteurova 7, 400 96 Ústí nad Labem, Czech Republic, E-mail: jaroslava.svobodova@ujep.cz.

${ }^{3}$ Faculty of Environmental and Manufacturing Technology, Technical University in Zvolen, Department of Mechanics, Mechanical Engineering and Design, Študentská 26, 96053 Zvolen, Slovakia, E-mail: kucera@tuzvo.sk

${ }^{4}$ Faculty of Engineering, Czech University of Life Sciences Prague, Department of Electrical Engineering and Automation, Kamýcká 129, 16521 Prague 6 - Suchdol, Czech Republic, E-mail: hromasova@tf.czu.cz

The design of internal combustion engine use plain bearings, pistons and piston-rod which are based on aluminium, brass. Further are used steels with coating based on aluminium and bronze. The paper describes the impact of contaminants in motor oil on wear of materials, which are used in production of parts of internal combustion engine. Reichert tester M2 for evaluation the lubricity from Petrotest Company was used in order to assess ability of motor oils to create proper lubricating film. Reichert tester M2 belongs to a group of equipment simulating real frictional contact. Wear particles come into oil in lubrication system, where they cause contamination and degradation of lubricating properties and consequently it may result in major failure of machines. Among these contaminants are included mainly water, fuel, water coolant, adhesive, abrasive and fatigue particles wear. The aim of research was focused only on oil contaminated with fuel including petrol, diesel and biobutanol.

Keywords: Wear particles, Reichert test, Particle morphology, Oil contamination

\section{Acknowledgement}

Paper was created with the grant support - CZU CIGA 2017 - 20153001 - Use of butanol in internal combustion engines.

\section{References}

[1] HU, E., KARL, D., BINGXUN,Y., RUHONG, S., YUFU, X., XIANGUO, H. (2017). Tribofilm formation and characterization of lubricating oils with biofuel soot and inorganic fluorides. Tribology International [online]. 107, 163-172 [cit. 2017-08-15]. DOI: 10.1016/j.triboint.2016.11.035. ISSN 0301679x.

[2] SANTOSH, K. K., RAJNISH G., SHYAM, P. (2016): A review of biofuel generated contamination, engine oil degradation and engine wear, Biofuels, DOI: 10.1080/17597269.2016.1224291

[3] ČERNÝ, J. (2006). Vlastnosti motorových olejů. Díl osmý-Palivo v oleji. AutoExpert. 2006, č. 10, s. 40-42. ISSN 1211-2380.

[4] FISCHER, T.E, Z ZHU, H KIM, D.S SHIN. (2000). Genesis and role of wear debris in sliding wear of ceramics. Wear [online]. 245(1-2), 53-60 [cit. 2017-08-15]. DOI: 10.1016/S0043-1648(00)00465-8. ISSN 00431648.

[5] BLAU, P. J., (1981) Mechanisms for transitional friction and wear behavior of sliding metals. Wear [online], 72(1), 55-66 [cit. 2017-08-15]. DOI: 10.1016/0043-1648(81)90283-0. ISSN 00431648.

[6] ALES, Z., PEXA, M., (2010). Diagnostika maziv s využitím laserového analyzátoru LASERNET FINES®-C, Časopis - Strojírenská technologie, Ročník XIV, zvláštní vydání, Univerzita Jana Evangelisty Purkyně, FVTM, Ústí nad Labem, s. 8-11. ISSN 1211-4162

[7] CARROL R.I., BEYNON J.H. (2007). Rolling contact fatigue of white etching layer. Part 2. Numerical results, Wear, 262 (9-10), pp. 1267-1273. ISSN 0043-1648

[8] DOBRANSKY, J., KREVEL, R., (2010). Analýza kvality použitého oleja a meranie vibraci hrotového sústruhu SV 18RA, Časopis - Strojírenská technologie, Ročník XIV, zvláštní vydání, Univerzita Jana Evangelisty Purkyně, FVTM, Ústí nad Labem, s. 33-36. ISSN 1211-4162

[9] MÜller, M., LEBEDEV, A., SVOBOdOVA, J., NÁPRSTKOVA, N., LEBEDEV, P. (2014) Abrasive-free ultrasonic finishing of metals. Manufacturing Technology, roč. 14, č. 3, s. 366-370. ISSN: 1213-2489. 
[10] MÜLLER, M., VALASEK, P. (2012): Abrasive wear effect on Polyethylene, Polyamide 6 and polymeric particle composites. Manufacturing Technology, Vol. 12, No. 12, pp. 55-59.

[11] RAHAMAN, M.L. a Liangchi ZHANG. An investigation into the friction and wear mechanisms of aluminium high silicon alloy under contact sliding. Wear [online]. 2017, 376-377, 940-946 [cit. 2017-08-15]. DOI: 10.1016/j.wear.2016.10.026. ISSN 00431648.

[12] WANG J., XING J., CAO L., Su W., GAO Y. (2010). Dry sliding wear behavior of Fe3Al alloys prepared by mechanical alloying and plasma activated sintering, Wear, 268 (2-3), pp. 473-480. ISSN 0043-1648.

[13] KHUONG, L. S., H. H. MASJUKI, N. W. M. ZULKIFLI, et al. (2017). Effect of gasoline-bioethanol blends on the properties and lubrication characteristics of commercial engine oil. $R S C A d v$ [online]. 7(25), 15005-15019 [cit. 2017-08-15]. DOI: 10.1039/C7RA00357A. ISSN 2046-2069.

[14] COSTA, H.L., M. M. OLIVEIRA JUNIOR, J. D. B. DE MELLO. (2017). Effect of debris size on the reciprocating sliding wear of aluminium. Wear [online]. 376-377, 1399-1410 [cit. 2017-08-15]. DOI:

10.1016/j.wear.2016.10.025. ISSN 00431648.

\section{Paper number: M2017116}

Copyright $($ 2017. Published by Manufacturing Technology. All rights reserved. 